\title{
Upaya Meningkatkan Kompetensi Mahasiswa dalam Praktik Asuhan Persalinan melalui Model Pembelajaran Praktik Klinik Kebidanan
}

\author{
Anita Megawati Fajrin, ${ }^{1}$ Farid Husin, ${ }^{2}$ Anita D. Anwar, ${ }^{3}$ Johanes C. Mose, ${ }^{4}$ Firman F.Wirakusumah, ${ }^{5}$ \\ Ishak Abdulhak ${ }^{6}$ \\ ${ }^{1}$ Mahasiswa Program Studi Magister Kebidanan Fakultas Kedokteran Universitas Padjadjaran \\ ${ }^{2}$ Departemen Epidemiologi dan Biostatistika Fakultas Kedokteran Universitas Padjadjaran \\ 3,4,5 Departemen Obstetri dan Ginekologi Fakultas Kedokteran Universitas Padjadjaran \\ ${ }^{6}$ Pengembangan Kurikulum Sekolah Pascasarjana Universitas Pendidikan Indonesia
}

\begin{abstract}
ABSTRAK
Praktik klinik merupakan bagian penting dari proses pendidikan kebidanan. Sistem praktik klinik kebidanan yang selama ini berjalan masih menuai banyak permasalahan sehingga berdampak pada kompetensi lulusan bidan. Berbagai permasalahan yang ditemui selama praktik klinik tidak mampu diatasi dengan baik, hal ini disebabkan oleh berbagai faktor yang memengaruhi, salah satunya adalah model pembelajaran praktik klinik yang kurang terstuktur yang berdampak pada rendahnya kualitas pengalaman klinik yang dimiliki oleh mahasiswa dan pada akhirnya berdampak pada kompetensi lulusan. Model pembelajaran yang dikembangkan dalam penelitian ini adalah model experiential learning yang dikembangkan oleh Kolb dengan menggunakan metode bedside teaching. Model pembelajaran ini akan memberikan kesempatan pada mahasiswa untuk mendapatkan pengalaman klinik sesuai dengan tahap perkembangannya. Tujuan dari penelitian ini adalah untuk menganalisis pengaruh penerapan model pembelajaran praktik klinik terhadap peningkatan kompetensi mahasiswa dalam memberikan asuhan persalinan. Penelitian ini menggunakan metode kuantitatif dengan rancangan penelitian quasi experimental pre-posttest design with nonequivalent control groups. Subjek penelitian ini adalah mahasiswa D-III Kebidanan yang telah lulus mata kuliah asuhan persalinan. Subjek dibagi menjadi 2 kelompok yaitu kelompok kontrol dan kelompok perlakuan. Kelompok kontrol adalah mahasiswa yang melakukan praktik klinik di RSUD Soreang sejumlah 26 orang, sedangkan kelompok perlakuan adalah mahasiswa yang melakukan praktik di RSUD Majalaya sejumlah 27 orang. Analisis yang digunakan adalah uji T tidak berpasangan, Mann Whitney, Chisquare, dan regresi logistik. Hasil penelitian menunjukkan model pembelajaran meningkatkan kompetensi mahasiswa sebesar 40,7\% dengan OR 17,2 (IK 95\% 2-146). Simpulan penelitian ini adalah model pembelajaran praktik klinik berpengaruh terhadap peningkatan kompetensi asuhan persalinan mahasiswa.
\end{abstract}

Kata kunci: model pembelajaran, kompetensi, praktik klinik. 


\title{
Improving Student's Competence Of Delivery Care by Clinical Learning Model
}

\begin{abstract}
Clinical learning is an important factor in the midwifery education. All this time, the system which has been running still reap the many issues that have an impact on the competence of graduates midwife. Various problems were encountered during clinical learning are not able to overcome properly, this is caused by various factors, one of which is ustructured learning model that adversely affects the quality of student's clinical experience and having an impact on the competence of graduates. In this study, Learning model developed by of Kolb's experiential learning and bedside teaching. This learning model will provide opportunities for students to gain clinical experience in accordance with the stage of development. The aim of this study is to analyze the effect of the application of clinical learning model to increase student competence in providing delivery care.This research design was quasi-experimental pre-posttest with nonequivalent control groups. Respondent were students of D-III Midwifery who had passed the delivery care course. Subjects were divided into 2 groups: control group and the treatment group. The control group were students who practice in Soreang hospitals with 26 respondents while the treatment group were students who practice in Majalaya hospitals with 27 respondents. The analysis used was independent T test, Mann Whitney, Chi-square, and logistic regression. The results showed there was $40,7 \%$ achieve competence in the treatment group, while there was $2,22 \%$ in the control group. Multivariate analysis showed that the application of clinical learning model effect on improving the competence of students $(p=0.009)$ with Odd Ratio 17.2 (95\% CI 2-146)

Conclusions of this research is the learning model of clinical practice affect in increasing the student competence of delivery care.
\end{abstract}

Keywords: Cilical learning model, competence

\section{Pendahuluan}

Bidan merupakan salah satu tenaga kesehatan yang memiliki peran penting dan strategis terutama dalam meningkatkan kesehatan ibu dan anak. Asuhan kebidanan yang berkualitas merupakan faktor penting dalam upaya meningkatkan kesejahteraan dan kesehatan ibu dan anak. Sampai dengan tahun 2013 jumlah pendidikan D III kebidanan di Indonesia meningkat pesat hingga mencapai 689 institusi, dan diperkirakan ada sekitar 60.000 bidan yang diluluskan setiap tahunnya. ${ }^{1}$ Namun demikian, banyaknya jumlah bidan yang ada di Indonesia tidak berbanding lurus dengan kualitas pelayanan yang diberikan. Hal ini disebabkan kompetensi lulusan bidan saat ini belum sesuai dengan kebutuhan masyarakat. Hasil survei World Health Organization (WHO) dan Kemenkes tahun 2012 didapatkan hasil bahwa hanya sekitar $15 \%$ kompetensi lulusan yang sesuai dengan kebutuhan kerja saat ini. ${ }^{2}$ Kondisi tersebut tentunya akan berdampak langsung pada kualitas pelayanan yang diberikan. Salah satunya dalam memberikan asuhan persalinan. Hasil penelitian yang dilakukan oleh Bartini dkk terhadap 53 bidan di RSUP Dr. Sardjito menunjukkan bahwa sebanyak 24,53\% kualitas pelayanan bidan berada dalam kategori kurang baik dan kondisi tersebut meningkatkan risiko terjadinya medical error dalam menentukan diagnosis, pencegahan infeksi, pemberian obat serta tindakan pertolongan persalinan sebanyak 3,8 kali. $^{3}$

Menurut WHO, upaya yang dapat dilakukan untuk menyelesaikan permasalahan tersebut adalah dengan meningkatkan kualitas sistem pendidikan, salah satunya dalam pembelajaran praktik klinik. Praktik klinik merupakan bagian penting dari proses pendidikan kebidanan yang bertujuan mengimplementasikan pembelajaran teori di kelas dan praktik laboratorium ke dalam situasi klinik. ${ }^{4}$ Kenyataannya, sistem praktik klinik kebidanan yang selama ini berjalan masih menuai banyak permasalahan sehingga belum dapat mencapai tujuan pembelajaran yang diharapkan. Beberapa permasalahan yang seringkali dihadapi pada pembelajaran praktik klinik adalah ketidaksesuaian antara metode bimbingan dengan tahap penguasaan kompetensi 
Anita Megawati Fajrin : Upaya Meningkatkan Kompetensi Mahasiswa Dalam Praktik Asuhan Persalinan melalui Model Pembelajarn Praktik Klinik Kebidanan

mahasiswa dan metode bimbingan yang tidak terstruktur menjadi faktor penyebab kurang optimalnya proses pembelajaran praktik klinik kebidanan. ${ }^{4}$ Diperlukan model pembelajaran yang dapat digunakan sebagai panduan bagi preseptor untuk membimbing mahasiswa dalam proses pembelajaran praktik klinik.

Model pembelajaran adalah suatu rencana atau pola yang dirancang untuk membantu mahasiswa mengorganisasikan pengalaman klinik, sehingga dapat mencapai kompetensi yang diharapkan. Dalam pendidikan kesehatan, pembelajaran eksperensial (experiential Learning) merupakan salah satu strategi yang dapat digunakan untuk membantu mahasiswa mengintegrasikan teori dan praktik. ${ }^{5}$ Strategi ini dibangun berdasarkan pemahaman bahwa, kompetensi klinik secara bertahap akan dicapai melalui pengalaman yang terjadi secara berulang dengan berbagai kasus klinik yang kompleks. Hasil penelitian menunjukkan bahwa, pembelajaran ekperensial dapat meningkatkan kemampuan berpikir kritis dan penalaran klinis mahasiswa yang menghadapi berbagai kasus dengan karakteristik yang bervariasi. ${ }^{6}$ Kemampuan berpikir kritis dan penalaran klinis merupakan struktur penting yang diperlukan untuk membangun kompetensi klinik mahasiswa.

Faktor lainnya yang dapat memengaruhi efektifitas pembelajaran praktik klinik adalah bedside teaching. Bedside teaching adalah suatu metode pembelajaran klinis yang melibatkan pasien, mahasiswa, dan pembimbing klinis yang dilakukan dalam konteks klinis. ${ }^{7}$ Metode ini akan melatih keterampilan mahasiswa dalam berkomunikasi dengan pasien, melakukan pemeriksaan fisik, penerapan etika klinis dan profesionalisme, hubungan interpersonal serta mengembangkan kemampuan nalar klinis mahasiswa yang pada akhirnya akan berdampak pada kompetensi lulusan bidan.

\section{Metode}

Rancangan penelitian ini adalah Quasi experimental dengan rancangan Pre-Posttest with noneqivalent control groups. Kelompok pembanding merupakan mahasiswa yang melakukan praktik klinik di RSUD Soreang, sedangkan kelompok perlakuan merupakan mahasiswa yang melakukan praktik klinik di RSUD Majalaya. Subjek dalam penelitian ini adalah mahasiswa yang telah lulus mata kuliah asuhan persalinan berjumlah 53 yang terbagi kedalam 2 kelompok, yaitu 27 orang pada kelompok perlakuan dan 26 orang pada kelompok pembanding.

Pengumpulan data dilakukan oleh preseptor (pada kelompok perlakuan) dan enumerator (pada kelompok kontrol) yang telah dilatih sebelumnya. Peneliti melakukan pemantauan jarak jauh dengan menggunakan teknologi Broadband Wireless Access (BWA). Pada akhir periode praktik dilakukan penilaian kompetensi subjek penelitian dengan menggunakan daftar tilik yang telah mengakomodir kemampuan kognitif keterampilan dan sikap mahasiswa dalam memberikan asuhan persalinan. Item penilaian daftar tilik ini dibangun berdasarkan studi literatur tentang asuhan persalinan dan dikembangkan dari penelitian sebelumnya yang telah melakukan survei terhadap 604 wanita di beberapa wilayah di Indonesia. Penelitian ini telah mendapatkan persetujuan etik dari Komite Etik Penelitian Kesehatan Fakultas Kedokteran Universitas Padjadjaran.

\section{Hasil}

Penelitian ini dilakukan terhadap mahasiswa D-III Kebidanan yang berasal dari beberapa institusi yang berbeda dengan karakteristik bervariasi. Perbedaan karakteristik subjek penelitian dapat memengaruhi hasil evaluasi. Untuk itu, agar hasil penelitian benar-benar murni dipengaruhi oleh intervensi, maka dilakukan penyetaraan karakteristik subjek penelitian yang meliputi nilai Indeks Prestasi (IP), motivasi serta nilai awal kompetensi yang disajikan pada tabel berikut ini 
Tabel 1. Karakteristik Subjek Penelitian

\begin{tabular}{|c|c|c|c|}
\hline \multirow{2}{*}{ Karakteristik } & \multicolumn{2}{|c|}{ Kelompok } & \multirow{2}{*}{ Nilai $p$} \\
\hline & Kontrol $(n=26)$ & Perlakuan (n=27) & \\
\hline $\begin{array}{ll}\text { 1. } & \text { Indeks Prestasi (IP) } \\
\text { Mean(SD) }\end{array}$ & $3,14(0,19)$ & $3,60(0,21)$ & $0,001 *$ \\
\hline $\begin{array}{l}\text { 2. Motivasi } \\
\text { Mean (SD) }\end{array}$ & $61,77(7,3)$ & $68,96(7,4)$ & $0,001 *$ \\
\hline $\begin{array}{l}\text { 3. Nilai Kompetensi awal } \\
\text { Median } \\
\text { Rentang }\end{array}$ & $\begin{array}{l}77,58 \\
(21-90)\end{array}$ & $\begin{array}{l}66,13 \\
(35-87)\end{array}$ & $0,358 * *$ \\
\hline
\end{tabular}

Tabel diatas menunjukkan bahwa terdapat perbedaan yang bermakna $(\mathrm{p}<0,05)$ baik indeks prestasi (IP) dan motivasi pada kedua kelompok penelitian, dimana indeks prestasi maupun motivasi pada kelompok perlakuan lebih baik dibandingkan kelompok kontrol. Sedangkan pada

Tabel 2 Perbedaan peningkatan kompetensi mahasiswa pada kedua kelompok penelitian

\begin{tabular}{lccc}
\hline \multirow{2}{*}{ Kelompok } & \multicolumn{2}{c}{ Kompetensi } & Nilai p* \\
\cline { 2 - 3 }$(\mathbf{n = 2 6 )}$ & $25(96,2 \%)$ & $\begin{array}{c}\text { Perlakuan } \\
(\mathbf{n = 2 7})\end{array}$ & $\mathbf{0 , 0 0 1}$ \\
Tidak Kompeten & $1(38 \%)$ & $11(40,7 \%)$ & \\
Kompeten & $3,8 \%$ & $40,7 \%$ & \\
Peningkatan $(\%)$ & &
\end{tabular}

nilai kompetensi awal terlihat tidak terdapat perbedaan yang bermakna $(\mathrm{p}>0,05)$ pada kedua kelompok. Dari karakteristik tersebut, diberikan intervensi berupa pembelajaran praktik klinik yang hasilnya disajikan pada tabel berikut

Keterangan : *Uji Chi-kuadrat

Tabel diatas menunjukkan bahwa pada kelompok perlakuan terdapat sebelas $(40,7 \%)$ dari 27 mahasiswa mengalami peningkatan kompetensi. Sedangkan pada kelompok kontrol hanya terdapat satu $(3,8 \%)$ dari 26 mahasiswa yang mengalami peningkatan kompetensi. Secara statistik menunjukkan adanya perbedaan peningkatan kompetensi yang bermakna antara kelompok perlakuan dan kontrol $(\mathrm{p}<0,05)$.

Pada penelitian ini subjek penelitian tidak setara karena pada karakteristik subjek penelitian memperlihatkan bahwa terdapat perbedaan yang bermakna motivasi dan indeks prestasi mahasiswa sehingga perlu dilakukan analisis multivariat untuk melihat adanya pengaruh kedua variabel tersebut terhadap variabel dependen yaitu kompetensi. Variabel bebas pada penelitian ini adalah model pembelajaran dan kemungkinan yang menjadi variabel perancu adalah motivasi dan Indeks Prestasi (IP). Analisis multivariat yang digunakan adalah regresi logistik. Pemilihan analisis ini dikarenakan skala ukur variabel terikatnya berupa variabel kategorik. Hasil analisis multivariat akan disajikan pada tabel berikut 
Anita Megawati Fajrin : Upaya Meningkatkan Kompetensi Mahasiswa Dalam Praktik Asuhan Persalinan melalui Model Pembelajarn Praktik Klinik Kebidanan

Tabel 3. Pengaruh Model Pembelajaran Praktik Klinik terhadap peningkatan kompetensi asuhan persalinan

\begin{tabular}{clrrrrr}
\hline & Variabel & \multirow{2}{*}{ Koefisien } & Nilai $\mathbf{p}^{*}$ & OR & \multicolumn{2}{c}{ IK 95\% } \\
Model awal & Model Pembelajaran & 3,577 & 0,005 & 35,7 & 3,01 & 424,1 \\
1 & Motivasi & 0,783 & 0,368 & 2,2 & 0,4 & 12,0 \\
& Indeks prestasi & $-1,417$ & 0,120 & 0,24 & 0,04 & 1,45 \\
& Constant & $-3,535$ & 0,002 & 0,03 & & \\
2 & Model_Pembelajaran & 3,707 & 0,003 & 40,7 & 3,5 & 470,8 \\
& Indeks Prestasi & $-1,293$ & 0,141 & 0,27 & 0,05 & 1,5 \\
& Constant & $-3,190$ & 0,002 & 0,04 & & \\
\hline Model & Model Pembelajaran & $\mathbf{2 , 8 4 4}$ & $\mathbf{0 , 0 0 9}$ & $\mathbf{1 7 . 2}$ & $\mathbf{2 , 0 2}$ & \multirow{2}{*}{$\mathbf{1 4 6 , 2}$} \\
& Constant & $-3,219$ & 0,002 & .040 & & \\
\hline
\end{tabular}

Keterangan : *Regresi Logistik $\mathrm{R}^{2}=0,302$

Tabel diatas menunjukkan bahwa variabel yang paling berpengaruh terhadap kompetensi adalah model pembelajaran dengan kekuatan hubungan OR 17,2 (IK 95\% 2-146) yang berarti model pembelajaran praktik klinik berpengaruh terhadap peningkatan kompetensi mahasiswa sebesar 17,2 kali dibandingkan pada kelompok kontrol. Selain itu berdasarkan model summary diperoleh $\mathrm{R}^{2}$ sebesar 0,302 yang berarti model pembelajaran praktik klinik berpengaruh terhadap kompetensi sebesar 30,2\%.

\section{Pembahasan}

Kompetensi klinik mahasiswa secara bertahap akan dikuasai melalui serangkaian pengalaman klinik yang kompleks dan terjadi secara berulang. Dalam perkembangannya kompetensi dicapai melalui proses yang kompleks. Davis et al (1995) membagi perkembangan mahasiswa ke dalam tiga tahapan dengan tingkat keterampilan yang berbeda-beda yaitu the beginner (Pemula), the transitional learner (Transisi), the Competent
Proficient (Mandiri). Masing-masing tahap penguasaan kompetensi mempunyai tujuan pembelajaran, sehingga metode pembelajara serta sistem evaluasi yang digunakan disesuaikan pada tingkat penguasaannya. Proses pembelajaran klinik yang dilakukan terstruktur dan bertahap merupakan aspek fundamental yang harus diperhatikan untuk mencapai kompetensi yang harapkan. ${ }^{8}$

Model pembelajaran yang dikembangkan dalam penelitian ini dibangun berdasarkan strategi pembelajaran eksperensia (experiential learning) dengan pendekatan student centered learning (SCL) dan metode bedside teaching (BST). Model ini akan memberikan kesempatan kepada mahasiswa untuk memperoleh pengalaman klinik secara terstruktur hingga mencapai kompetensi yang diharapkan

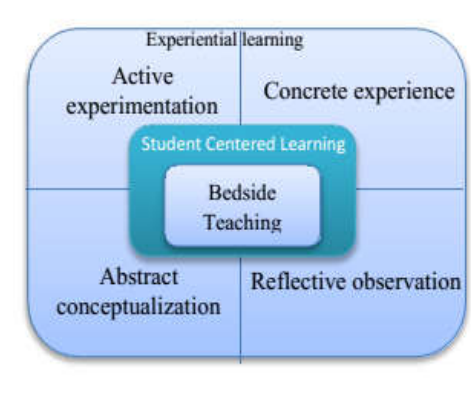

Model Pembelajaran

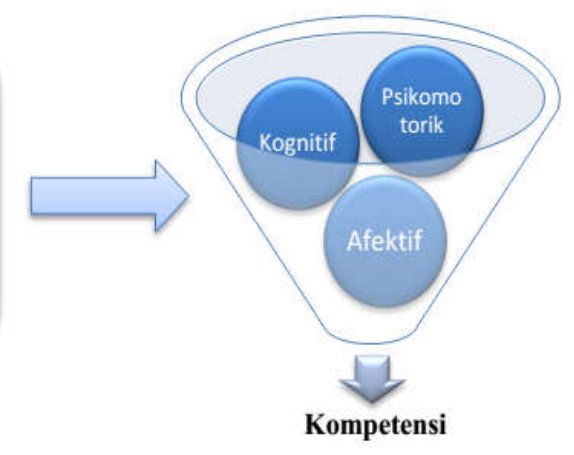

Kompetensi

Gambar 1. Model Pembelajaran Praktik Klinik Kebidanan 
Tabel 2 memperlihatkan bahwa pada kelompok perlakuan terdapat peningkatan jumlah mahasiswa yang kompeten yaitu sebelas $(40,7 \%)$ dari 27 mahasiswa. Sedangkan pada kelompok kontrol hanya terdapat satu $(3,8 \%)$ dari 26 mahasiswa yang mencapai kompeten dan secara statistik menunjukkan adanya perbedaan yang bermakna antara kelompok perlakuan dan kontrol $(\mathrm{p}<0,05)$.

Hasil penelitian ini sesuai dengan teori yang dibangun bahwa model pembelajaran ini akan memfasilitasi mahasiswa untuk belajar secara utuh yang menggabungkan aspek kognitif, afektif dan psikomotorik saat berinteraksi dengan pasien $^{9,10}$ Penelitian yang dilakukan terhadap mahasiswa terapi okupasi menunjukkan bahwa, pembelajaran eksperensial dapat meningkatkan kemampuan berpikir kritis dan penalaran klinis mahasiswa yang menghadapi berbagai kasus dengan karakteristik yang bervariasi. $^{6}$ Kemampuan berpikir kritis dan penalaran klinis merupakan struktur penting yang diperlukan untuk membangun kompetensi klinik. Bimbingan yang memadai ketika mahasiswa berinteraksi langsung dengan pasien dapat melatih keterampilan mahasiswa dalam berkomunikasi, melakukan anamnesis, menegakkan diagnosis, pemeriksaan fisik dan merencanakan asuhan yang akan diberikan kepada pasien. ${ }^{7,10,11}$

Pembelajaran praktik klinik tidak hanya memberikan kesempatan kepada mahasiswa untuk mengembangkan pengetahuan dan keterampilannya, akan tetapi juga sikap yang diperlukan dalam memberikan asuhan kepada pasien. Praktik klinik akan memberikan pengalaman kepada mahasiswa untuk belajar menghormati hak dan martabat pasien, berempati serta bertanggung jawab terhadap asuhan yang diberikan. ${ }^{12}$ Salah satu keuntungan dari bedside teaching adalah, preseptor dapat melakukan pengamatan terhadap asuhan yang diberikan oleh mahasiswa secara langsung sehingga dapat memberikan umpan balik (feedback) terhadap kinerja mahasiswa. Umpan balik merupakan komponen penting dalam pembelajaran praktik klinik yang bermanfaat untuk meningkatkan kemampuan mahasiswa, memberikan arahan yang dapat meningkatkan kepercayaan diri, motivasi dan harga diri mahasiswa. ${ }^{13}$

Faktor lain yang dapat menunjang efektifitas pembelajaran praktik klinik adalah penggunaan modul pembelajaran. Beberapa hasil penelitian menunjukkan bahwa kendala yang seringkali menjadi penyebab tidak optimalnya penerapan bedside teaching adalah preseptor kurang percaya diri untuk membimbing mahasiswa pada pasien langsung karena kurangnya pengalaman yang dimiliki oleh preseptor dan minimnya pengetahuan yang dimiliki mahasiswa. ${ }^{17}$ Modul pembelajaran praktik klinik dapat membantu baik mahasiswa maupun preseptor untuk beradaptasi dengan kurikulum klinis sehingga dapat secara konsisten menerapkan bedside teaching. Selain dapat digunakan sebagai panduan dalam menjalankan praktik klinik, modul juga disusun untuk membantu mahasiswa untuk mengorganisasikan pengalaman kliniknya secara terstuktur. Schwartz dkk (1998) dalam penelitiannya mengemukakan bahwa penggunaan modul efektif untuk meningkatkan keterampilan klinik mahasiswa. Hal ini disebabkan dengan adanya modul, instruksi pembelajaran cukup jelas untuk dipelajari oleh mahasiswa dan merangsang mahasiswa untuk berlatih hingga mencapai kompetensi yang diharapkan. ${ }^{16}$

Model pembelajaran yang dikembangkan berdasarkan tahapan kompetensi memungkinkan proses pembelajaran mahasiswa menjadi lebih terstruktur. Kesesuaian model pembelajaran dengan tahapan kompetensi berpengaruh positif terhadap efektifitas pembelajaran praktik klinik yang pada akhirnya akan berdampak pada ketercapaian kompetensi yang ditentukan. ${ }^{17}$ Tahap pemula merupakan fase awal untuk membangun kompetensi mahasiswa di lahan praktik. Pada tahap ini metode pembelajaran yang diberikan adalah memfasilitasi mahasiswa untuk melakukan orientasi lingkungan klinik dan tugas pembelajaran yang bertujuan untuk membangun perkembangan kognitif dan kesiapan. Berbagai hasil penelitian menunjukkan bahwa orientasi klinik dapat membantu mahasiswa "engage" ke dalam proses pembelajaran praktik klinik sehingga menjadi lebih efektif. ${ }^{18}$ Demikian pula halnya dengan proses pembelajaran transisi, pada fase ini mahasiswa difasilitasi untuk memberikan asuhan kepada pasien yang dilakukan secara bertahap dengan bimbingan penuh preseptor. Metode ini dibangun berdasarkan teori yang menyatakan bahwa keterampilan (psikomotorik) dicapai melalui perkembangan yang hirarkis, dimana pencapaian tujuan belajar dicapai melalui penguasaan bagian-bagian keterampilan terlebih dahulu hingga mendekati tujuan pembelajaran akhir. ${ }^{19}$ 
Hasil analisis bivariat memperlihatkan bahwa kelompok perlakuan memiliki persentase peningkatan lebih besar dibandingkan kelompok kontrol. Namun jika dilihat persentase mahasiswa yang tidak kompeten, maka penerapan model pembelajaran praktik klinik ini belum mencapai hasil yang optimal karena masih terdapat 59,3\% mahasiswa yang tidak kompeten pada kelompok perlakuan. Tidak tercapainya kompetensi mahasiswa dipengaruhi oleh beberapa faktor internal maupun eksternal yang saling berinteraksi. Faktor internal yang memengaruhi kompetensi mahasiswa meliputi demografi, kemampuan intelektual, inisiatif, minat, motivasi serta pengalaman klinik sebelumnya, sedangkan faktor eksternal meliputi faktor sosial, budaya, faktor lingkungan klinik dan faktor spiritual. ${ }^{20}$

Tabel 1 menunjukkan bahwa terdapat perbedaan yang bermakna motivasi antara kelompok kontrol dan perlakuan, motivasi pada kelompok perlakuan lebih baik dibanding kelompok kontrol. Secara teori dinyatakan bahwa seseorang dengan motivasi yang tinggi akan mendapatkan hasil belajar yang lebih baik. ${ }^{15}$ Demikian pula halnya dengan indeks prestasi mahasiswa. Indeks prestasi yang dicapai mahasiswa berhubungan dengan tingkat intelegensinya. Pada penelitian ini, rerata indeks prestasi pada kelompok perlakuan lebih baik dibandingkan kelompok kontrol (tabel 1) dan secara statistik terdapat perbedaan yang bermakna.

Hasil analisis multivariat menunjukkan bahwa variabel yang paling berpengaruh terhadap kompetensi adalah model pembelajaran dengan OR 17,2 (IK 95\% 2-146) yang berarti model pembelajaran praktik klinik berpeluang untuk meningkatkan kompetensi mahasiswa sebesar 17,2 kali dibandingkan model pembelajaran konvensional. Dengan demikian, dalam penelitian ini indeks prestasi dan motivasi tidak berpengaruh terhadap peningkatan kompetensi mahasiswa (tabel 3)

Berdasarkan hasil analisis multivariat diperoleh nilai $\mathrm{R}^{2}$ sebesar 0,302 yang berarti model pembelajaran praktik klinik hanya berpengaruh terhadap kompetensi sebesar 30,2\%. Kompetensi mahasiswa dipengaruhi oleh faktor lainnya sebesar $69,8 \%$, salah satunya adalah lingkungan praktik klinik. Lingkungan praktik merupakan salah satu komponen penting dalam proses pembelajaran praktik klinik. Lingkungan yang baik secara fisik maupun emosional dapat mendukung mahasiswa untuk mengembangkan dirinya. Adanya sikap saling menghormati, kerjasama, dukungan dan kepercayaan antara preseptor, mahasiswa dan staf ruangan akan membentuk lingkungan belajar yang berkualitas. ${ }^{4}$ Hasil pengamatan peneliti yang dilakukan melalui teknologi Broadband Wireless access (BWA) memperlihatkan bahwa hubungan yang terbangun antara preseptor dan mahasiswa belum terjalin dengan baik. Interaksi yang dilakukan hanya terbatas pada saat proses bedside teaching. Setelah dilakukan konfirmasi, mahasiswa menyatakan bahwa mereka merasa kesulitan dalam membina hubungan baik dengan preseptor dan seringkali merasa takut untuk berinteraksi. Adanya persepsi yang kurang baik tentang lingkungan klinik tentunya akan berpengaruh negatif terhadap kompetensi mahasiswa.

Faktor lain yang kemungkinan berpengaruh terhadap peningkatan kompetensi klinik mahasiswa adalah preseptor. Preseptor mempunyai peran yang krusial dalam mewujudkan proses pembelajaran praktik yang berkualitas. Beberapa temuan pada saat dilakukan pemantauan adalah preseptor tidak menerapkan model pembelajaran secara optimal. Preseptor tidak selalu mendampingi mahasiswa ketika memberikan asuhan kepada pasien. Pada konteks ini, preseptor hanya memberikan instruksi tanpa melakukan pengawasan terhadap asuhan yang diberikan. Ketidakhadiran preseptor saat mahasiswa memberikan asuhan menjadi salah satu faktor penyebab tidak terevaluasinya kompetensi mahasiswa. Berdasarkan hasil pengamatan peneliti yang ditunjang catatan harian pada modul mahasiswa, aspek lain yang seringkali tidak dilakukan oleh preseptor adalah pemberian umpan balik (feedback) terhadap kinerja mahasiswa, sehingga mahasiswa tidak mengetahui kekurangannya dalam memberikan asuhan. Tidak diberikannya umpan balik memungkinkan mahasiswa membandingkan dirinya dengan mahasiswa lainnya yang lebih senior atau mengevaluasi dirinya sendiri dengan cara yang tidak tepat. Pada akhirnya kondisi ini dapat menurunkan harga diri dan berpengaruh negatif terhadap hasil belajar di praktik klinik. ${ }^{13}$

Kendala lainnya yang menjadi penyebab tidak optimalnya penerapan model pembelajaran praktik klinik ini adalah kurangnya pemahaman mahasiswa tentang penggunaan modul pembelajaran. Mahasiswa merasa kesulitan dalam menerapkan modul ke dalam proses 
pembelajaran karena terdapat banyak kegiatan yang tidak biasa dilakukan pada praktik klinik sebelumnya, hal ini yang kemungkinan menjadi penyebab kurangnya efektifitas penggunaan modul untuk mendukung kegiatan belajar mahasiswa. Komponen lainnya yang berpengaruh terhadap kualitas pembelajaran praktik adalah dosen pembimbing. Selain bertanggung jawab atas perencanaan praktik klinik, dosen pembimbing juga harus menjamin keterlaksanaan model pembelajaran yang telah dirancang sebelumnya. Teknologi BWA diharapkan mempermudah dosen pembimbing untuk melakukan pemantauan terhadap proses pembelajaran yang sedang berlangsung serta melakukan koordinasi baik dengan preseptor maupun mahasiswa jika terdapat kondisi yang berjalan tidak sesuai dengan standar yang telah dirumuskan. Adanya koordinasi yang berkesinanmbungan juga diharapkan dapat menfasilitasi mahasiswa maupun preseptor ketika menemukan hambatan mengimplementasikan model pembelajaran Pada penelitian ini, temuan yang diperoleh berdasarkan hasil pengamatan langsung adalah proses bimbingan yang dilakukan oleh dosen pembimbing belum terintegrasi dengan model pembelajaran, sehingga kurang menunjang implementasi model pembelajaran yang telah dibangun sebelumnya.

\section{Simpulan}

Simpulan penelitian ini adalah model pembelajaran dapat meningkatkan kompetensi mahasiswa sebesar 40,7\% dengan OR 17,2 (IK $95 \%$ 2-146).

\section{Daftar Pustaka}

1. WHO, UNFPA, ICM. State of World midwifery 2014. 2014.

2. Pardede D. Survey Kualitas Pendidikan Keperawatan \& Kebidanan di Indonesia (WHO) Tahun 2011-2012. Batam; 2013.

3. Bartini I, Emilia O, Adi U. Analisis Self Reported Asuhan Persalinan oleh Lulusan DIII Kebidanan dan Medical Error. Ber Kedokt Masy. 2011;27(3):131-7.

4. Firoozehchian F, Ezbarmi ZT, Dadgaran I. NursingMidwifery Students and Teachers' Views of Effective Factors in Clinical Education. Procedia - Soc Behav Sci [Internet]. Elsevier B.V.; 2012 [cited 2014 Dec 13];47:1832-7. Available from: http://linkinghub.elsevier.com/retrieve/pii/S1877042812 026444

5. Lisko SA, O`dell V. Integration of Theory and Practice:
Experiental Learning Theory and Nursing Education. Nurs Educ Perspect. 2010;31(2):106.

6. Coker P, Otr L. Effects of an Experiential Learning Program on the Clinical Reasoning and Critical Thinking Skills of Occupational Therapy Students. J Allied Health. 2010;39(4):280-6.

7. Peters M, Ten Cate O. Bedside teaching in medical education: a literature review. Perspect Med Educ [Internet]. 2014 Apr [cited 2015 Feb 2];3(2):76-88. Available from: http://www.pubmedcentral.nih.gov/articlerender.fcgi?art $\mathrm{id}=3976479 \&$ tool $=$ pmcentrez\&rendertype $=$ abstract

8. Pitt V, Powis D, Levett-Jones T, Hunter S. Factors influencing nursing students' academic and clinical performance and attrition: an integrative literature review. Nurse Educ Today [Internet]. Elsevier Ltd; 2012 Nov [cited 2016 Jan 21];32(8):903-13. Available from: http://www.ncbi.nlm.nih.gov/pubmed/22595612

9. Joyce PD, Robert H. Structured Experiential Learning Exercises : A Facilitation to More ... 1981;

10. Ramani S. Twelve tips to improve bedside teaching. MedTeach 2003; 25: 112-5. Med Teach. 2003;25(2112115).

11. Shehab A. Clinical Teachers' Opinions about Bedsidebased Clinical Teaching. Sultan Qaboos Univ Med. 2013;13(February):121-6.

12. Branch WT. Teaching professional and humanistic values: Suggestion for a practical and theoretical model. Patient Educ Couns [Internet]. Elsevier Ireland Ltd; 2015;98(2):162-7. Available from: http://dx.doi.org/10.1016/j.pec.2014.10.022

13. Clynes MP, Raftery SEC. Feedback: an essential element of student learning in clinical practice. Nurse Educ Pract [Internet]. Elsevier Ltd; 2008 Nov [cited 2014 Dec 20];8(6):405-11. Available from: http://www.ncbi.nlm.nih.gov/pubmed/18372216

14. Paritakul P. Optimising Bedside Teaching in Obstetrics and Gynaecology. Thai J Obstet ang Gynaecol. 2014;22(2):61-6.

15. Mosalanejad L, Hojjat M, Badeyepeyma Z. A Comprehensive Evaluation of the Quality and Barriers of Bedside Teaching from Professors ' Point of View. 2013;5(2):233-9.

16. Sloan DA, Donnely MB, Zweng TN, Lieber A, Yu G, Griffith $\mathrm{C}$, et al. The Structured Clinical Instruction Module A Novel Strategy for Improving the Instruction of Clinical Skills.pdf. 1995. p. 605-10.

17. Burns C, Beauchesne M, Ryan-Krause P, Sawin K. Mastering the preceptor role: challenges of clinical teaching. J Pediatr Health Care [Internet]. 2000 [cited 2014 Dec 20];20(3):172-83. Available from: http://www.ncbi.nlm.nih.gov/pubmed/16675378

18. Baltimore JJ. The Hospital Clinical Preceptor : Essential Preparation for Success.

19. Dorothy E R, Oerman MH. Clinical Teaching in Nursing Education. Jones \& Bartlett; 1999. 40,161,210-211,227228,241,251 p.

20. Billings DM, Halstead JA. Teacing in Nursing: A guide for faculty. St.Louis, Missouri: Elevier; 2012. 26,317$318,321 \mathrm{p}$. 